\title{
The impact of strategic management on the development of the Integrated Service Point to support competitiveness in the conditions of globalization
}

\author{
Simona Jaculjaková1,*, and Jana Štofková ${ }^{1}$ \\ ${ }^{1}$ University of Zilina, Faculty of Operation and Economics of Transport and Communications, \\ Department of Communications, Univerzitna 1, 01026 Zilina, Slovakia
}

\begin{abstract}
.
Research background: The priorities of informatization cover a wide range of areas that need to be constantly addressed in the business sphere in the period of globalization. Optimization and automation of public administration processes together with the priority of categorization of services according to life situations ensures a qualitative change in the provision of public administration services. The paper deals with the influence of strategic management on the development of the Integrated Service Point to support the competitiveness of the national postal operator as a strategic partner of e-Government in the conditions of globalization.

Purpose of the article: It is the implementation of primary research, which is focused on finding out the impact of strategic management on the development of ISP. The research is focused on potential new services that would be welcomed by customers - citizens of the Žilina self-governing region at the ISP workplace operated by Slovak Post. As part of the development of strategic management at Slovak Post, the acceptance of new services at the ISP workplace may lead to higher customer satisfaction and the acquisition of new potential customers and thus to the promotion of competitiveness in the conditions of globalization.

Methods: The article uses methods such as excerpting, analysis of the current state, statistical methods, primary research, induction, deduction, etc. Findings \& Value added: The output of the research is the creation of a proposal for a technological process that customers would welcome as a new ISP service of Slovak Post to support competitiveness in the development of e-Government in the conditions of globalization.
\end{abstract}

Keywords: Globalization; Strategic management; e-Government; Integrated service point; Conversion from e-mail box

JEL Classification: $F 01 ; F 69 ; D 90$

\footnotetext{
* Corresponding author: simona.jaculjakova@fpedas.uniza.sk
} 


\section{Introduction}

Globalization is an extraordinary concept. It is a complicated concept that burst upon the world relatively recently, but soon became a household concern. It is a concept that was rarely used until the 1990s, but processes of globalization had been happening for centuries. [1] In earlier eras of globalization, the importance of agglomeration was represented by a fairly simple relationship between the scale of the city and the scale of country-empire, whereas during the inter-war years of the twentieth century, this relationship began to change and to evolve into a much more complex set of relationships that are seen today. [2] With enhanced globalisation and rapid industrialisation, the world's output is continuously increasing. [3] The process of globalization has various consequences that affect individual sectors of the national economy. [4] With the increase of globalization, for a variety of reasons growing numbers of people go abroad to volunteer. [5] The migration of educated people is one of the consequences of globalization. Such migration occurs in various sectors and one of them are the areas of informatization, digitalisation, but also the area of the public sector, which is eGovernment.

Electronic government has several aspects, including social, technical, economic, political, and administrative. Most authors define the e-Government as system that uses Information and Communication Technology (ICT) in order to provide citizens with a better public services. [6, 7] In other words, e-Government refers to the use of ICTs by governments to promote access and delivery of government services and operations for its citizens. [8] Electronic government aims to make public institutions more transparent and accountable. [9] E-Government increases the convenience and accessibility of government services and information to citizens. [10,11] Electronic government is a global trend with far-reaching benefits if implemented in the optimal way. [12] All nations, whether they are developed or developing economies, invest in the development of strategies furthering their e-government agenda. [13]

Strategic management in the field of e-Government is very important, because it is necessary to focus on the priorities of informatization and digitalisation in the postal sector, which is a common provider of e-Government services. $[14,15]$ For this reason, we applied strategic management in the area of e-Government through a selected workplace of the postal sector, which is the Integrated Service Point (ISP). The given workplace is analysed within a specific provider, which is the national postal operator of Slovakia. The ISP workplace provides, according to the Act 305/2013 Collections of e-Governance Laws, assisted communication of individuals and legal entities with public authorities. [16] The service provided may be an extract or a transcript from public registers that can be used for legal purposes.

Such a focus on a specific workplace has also been implemented because in the current socio-economic environment, it is necessary to face challenges such as the emergence of new technologies in globalization and the growing demands from customers and businesses. [1] Automation and optimization of processes at the ISP workplace is necessary mainly for the purposes of public interest, precisely in order to ensure qualitative changes in the provision of public administration services, which citizens actually use in individual life situations.

\subsection{Analysis of the provision of selected workplaces}

In the Slovak Republic, the services of the ISP workplace are provided either by the national postal operator or by individual public administration bodies. Within the provision of electronic e-Government services, Slovak Post is a strategic partner mainly due to the fact that it has a very dense postal network, which ensures the provision of these services to individuals and legal entities throughout the Slovakia. Slovak Post provides ISP services at 
approximately 600 workplaces. In the following picture you can see the network of eGovernment services provided at the ISP workplace.

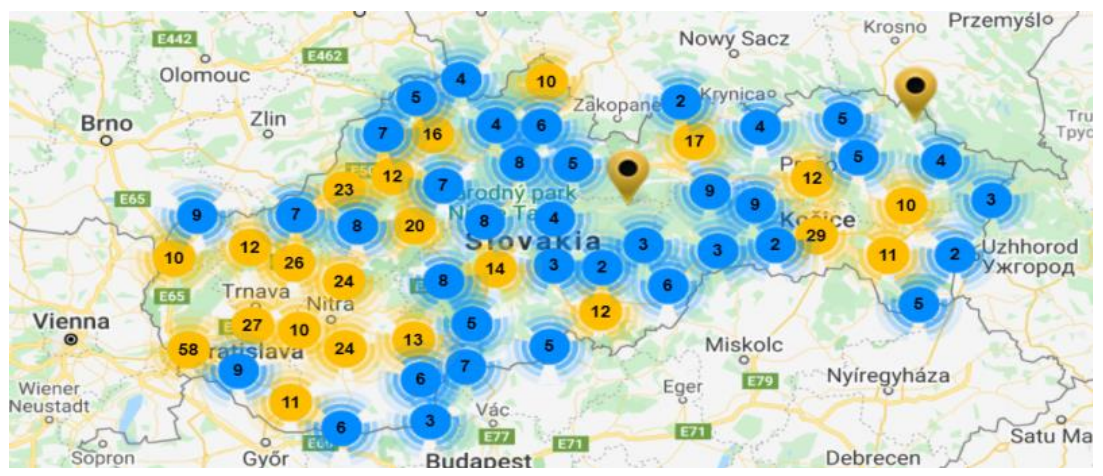

Fig. 1. Network of branches of the ISP workplace in the Slovak Republic.

Slovak Post provides basic and additional e-Government services through the ISP workplace.

Among the basic services of the ISP workplace at Slovak Post, we include:

- Extract from the Commercial Register for legal purposes,

- Extract from the title deed for legal purposes,

- Criminal records,

- $\quad$ Extract from the criminal record for legal purposes.

In addition to these basic services, the ISP workplace provides other additional services, including:

- Guaranteed conversion,

- Certification of documents by guaranteed conversion,

- $\quad$ Address change notification. [17]

Subsequently, we compared services at the ISP workplace with a similar Czech Point workplace, which is provided by the national postal operator in the Czech Republic, which is Czech Post. As part of the comparison, we must evaluate that Czech Point provides many more services, either from the basic or additional portfolio. In the following table 1 we can see a comparison of the number of provided basic and additional services of the ISP workplace at Slovak Post and the Cezch Point workplace at Czech Post.

Table 1. Comparison of services provided at selected workplaces

\begin{tabular}{|c|c|}
\hline ISP - Slovak Post & Czech Point - Czech Post \\
\hline Number of basic e-Government services provided \\
\hline 4 & 15 \\
\hline Number of additional e-Government services provided \\
\hline 3
\end{tabular}

Table 1 shows that the ISP workplace operated by Slovak Post provides only 4 basic and 3 additional services. A similar Czech Point workplace, operated by Czech Point provides up to 15 basic and 5 additional services. For this reason, it is necessary to focus on the development of electronic services provided within e-Government to the ISP workplace. [18, 19] 
After the implementation of the given comparison, it would be a good strategic step to focus our attention to the services that would be currently needed for citizens, sole traders and entrepreneurs. For this reason, it is necessary to carry out primary research, which would focus on what new services would be received by individuals or legal entities in the workplace.

In this scientific article, we theoretically defined terms such as globalization, strategic management, e-Government and the ISP workplace. Subsequently, we analyzed the current state of providing services of the Integrated Service Point in Slovakia with a similar workplace in the Czech Republic, which is Czech Point. These workplaces were surveyed through a selected provider, which is the country's national postal operator. In the practical part, it is necessary to conduct primary research focused on potential new services within the ISP workplace. After evaluating the primary research, it is necessary to select a specific service that could be implemented at the workplace.

\section{Methodology}

The aim of this scientific article is to implement strategic management at the workplace of the ISP by Slovak Post. The reason of this implementation is in ensuring the categorisation of the services provided according to the life situations, which means that the introduction of new services that citizens currently need is required. Subsequently, it is necessary to implement qualitative changes in the services provided to the public but also to the exercise of public power. For this reason, it was necessary to carry out primary research, which focused on potential new services that would be welcomed by individual citizens of the Žilina Region at the ISP workplace. After evaluating the primary research, we found out that the given citizens would accept the conversion of a document from an electronic mailbox as a new service. Subsequently, it was necessary to implement a precise technological procedure within which a potential new approach to e-Government could be provided at a given workplace.

To achieve this result, it was necessary to use these methods of excerpting, analysis of the current state, statistical methods, primary research, induction and deduction. The excerpting method was used to define the theoretical basis such as globalization, strategic management, e-Government, etc. In the analysis of the current state, it was necessary to find out the current state of providing e-Government services at the ISP workplace. Subsequently, statistical methods were used to calculate the minimum sample. Within the scientific article, primary research was used to find out what potential new ISP services that citizens would use. The respondents who participated in the research are from the Žilina region. Subsequently, it was found that as of 31 December 2019, the exact number of inhabitants with permanent residence over 15 years was just 582241 . The addressed respondents had to be over 15 years old, due to the fact that in order to provide the services by ISP, it is necessary to have an electronic ID card with a chip and 15 year olds recieve this type of ID. In Table 1 you can see the procedure for calculating the minimum number of respondents that need to be determined.

Table 2. Minimum sample calculation procedure

\begin{tabular}{|c|c|}
\hline & Formula for calculating the basic file: \\
\hline $\begin{array}{l}\text { Basic file } \\
\text { calculation }\end{array}$ & $\begin{array}{l}\qquad n \geq \frac{\left(t_{1-\frac{\alpha}{2}}\right)^{2} \cdot \sigma^{2}}{\Delta^{2}} \\
\text { where: } \\
n \text { - is the minimum sample size (minimum number of respondents), }\end{array}$ \\
\hline
\end{tabular}




\begin{tabular}{|c|l|}
\hline & $\begin{array}{l}t_{1-\frac{\alpha}{2}}-\text { is the critical value determined from the tables, } \\
\text { For the calculation of the basic sample, it was necessary to determine the } \\
\text { error rate, which is set in the range from } 5 \% \text { to } 10 \% \text {. As part of the } \\
\text { implementation of the calculation, we determined the error rate to be only } \\
6 \% \text { in order to be able to meet the minimum sample. } \\
\sigma=\sqrt{p(1-p)} \text { is the standard deviation, } \sigma^{2} \text { - is the variance } \\
\sigma^{2}=\sigma=\sqrt{p(1-p)}=\sqrt{0,5 *(1-0,5)}=0,5 \\
p-\text { base file variability, if the value is not known, a value of } 0,5 \text { is } \\
\text { determined, } \\
\Delta-\text { is the maximum allowable margin of error. }\end{array}$ \\
\hline $\begin{array}{c}\text { Calculation of the } \\
\text { minimum sample }\end{array}$ & $\begin{array}{l}\text { With 99,5\% confidence and } 6 \% \text { error margins, the minimum sample size is } \\
161 \text { respondents. }\end{array}$ \\
\hline $\begin{array}{c}\text { Number of } \\
\text { respondents } \\
\text { addressed }\end{array}$ & \multicolumn{1}{c}{173} \\
\hline
\end{tabular}

Table 2 shows that with $99,5 \%$ confidence and $6 \%$ error margins, 161 respondents had to be contacted. Within the given primary research, we managed to address up to 173 respondents, which means that we met the required minimum number of respondents with a given number.

\section{Results}

As part of the implementation of the primary research, it was necessary to find out from the citizens of the Zilina region what new approach they would adopt in the field of eGovernment at the ISP workplace. The relevant question of primary research was: , Which of the following services would you welcome as a new e-Government service? ". This question was closed and could be answered by all respondents. On this issue, it was necessary to identify potential new services that could be provided under e-Government at Slovak Post. Among the potential new services within e-Government we have included:

- Image from the cadastral map,

- $\quad$ Filing a complaint, lawsuit, appeal through an ISP,

- Convert a document from an e-mail box.

The other two options for answering the question were either: „None of the above“ or „others “. Most respondents in the Žilina Region would accept among the new e-Government services: „Conversion of a document from an electronic mailbox". This answer was given by $126(72,8 \%)$ respondents. This issue was important for future proposals that could be made in order to create a new approach that would be used by both natural and legal persons. Subsequently, we can see a graphical evaluation of the question (Fig. 2).

After the evaluation, it is necessary to design the technological procedure of the new approach at the ISP workplace, which is the conversion of a document from an electronic mailbox.

The new Mailbox Conversion service would be implemented through an active mailbox. Such a box is used by citizens and entrepreneurs to receive electronic official documents (decisions) from public administration bodies. 


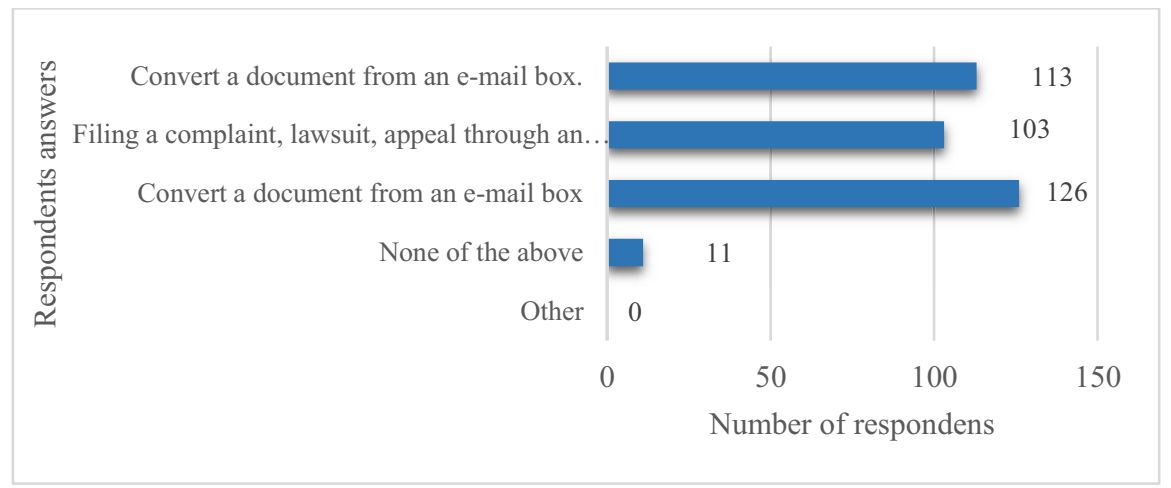

Fig. 2. Selection of new e-Government services.

Legal entities are obliged to set up an electronic mailbox as of 1 July 2017, which are registered in the Commercial Register and carry out their business activities in the territory of Slovakia. This obligation imposed by the state is necessary because, through an active electronic mailbox, public administration bodies would not send official documents in paper form but would be sent to the already mentioned electronic mailbox. Citizens of Slovakia do not have such an obligation to activate the electronic mailbox, but they can use it on a voluntary basis. In the event that the subject, i.e. a citizen, self-employed person or entrepreneur, needs an official document in paper form, he could use the currently proposed ISP service at Slovak Post. Electronic mailbox conversion would be provided only to applicants who present an eID card to the ISP employee, i.e. an electronic identity card with a chip. The ISP employee would have to obtain a power of attorney to access the mailbox. The applicant for this service would have to sign a power of attorney to access the ISP employee's e-mail box.

The e-mail conversion service would work in such a way that the applicant of this service would come to the ISP workplace together with the eID card and would announce that he wanted to create a document conversion from the e-mail box. An employee of Slovak Post would ask the customer to insert the eID card into the reading device. By reading the eID card, it would read data from the applicant to the employee in the information system.

After obtaining this information, the employee would fill in the necessary information and then print out two authorizations, which would be signed by the applicant. One power of attorney would be for the applicant and the other for further processing at the ISP workplace. After the given signature, the applicant would log in to the given e-mail box using the code assigned to the eID card on the reading device. The employee's e-mail box was shown to the employee. This e-mail box would be shown to the applicant on a tablet. In the given e-mail box, individual folders would appear in which various documents would be located. The applicant determines exactly which document will be converted. In the Fig. 3 we can see the appearance of the e-mail box. This document is then printed from the e-mail box. It is checked whether the printed document matches the document in the e-mail box. If such a document matches, an employee of Slovak Post will print a certification clause and sign it. The employee then links the certification clause together with the printed document. Subsequently, the employee stamps the document with the stamp of Slovak Post from both sides of the merged document. If the applicant wishes to print more than one document or to make more than one copy, he / she must notify the ISP employee in advance. 


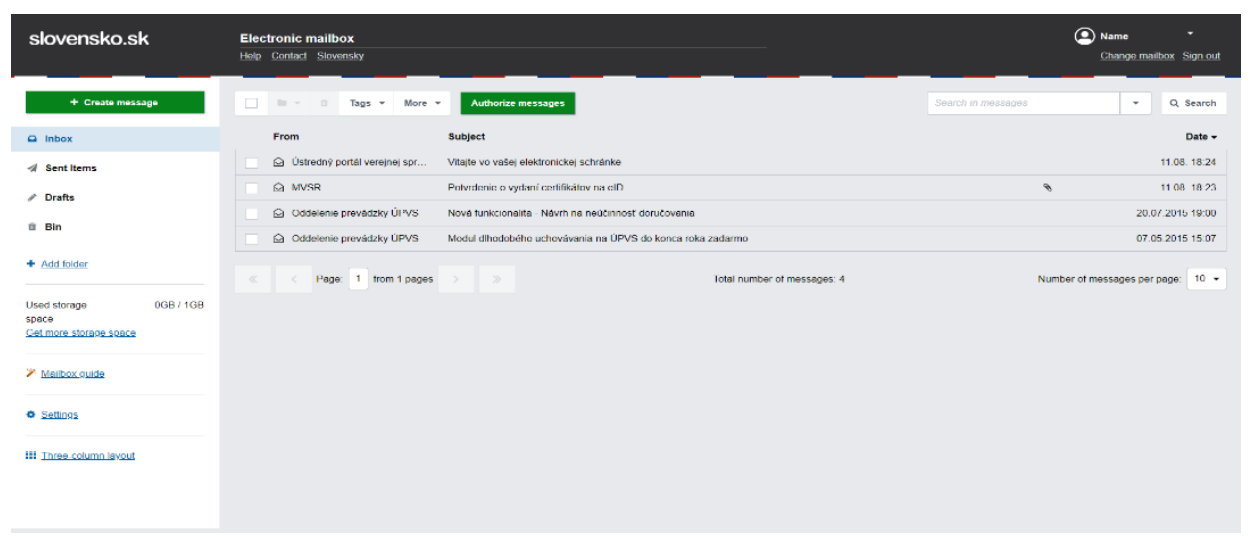

Fig. 3. The appearance of the e-mail box.

Sending documents to an electronic mailbox would be practical because a citizen, selfemployed person or entrepreneur could find the necessary documents at any time without having to physically own them. Conversion from the electronic mailbox would be used in solving various official matters where it is necessary to have documents in paper form. It is a major strategic step in providing new services that would be accepted by tax citizens. This approach could be tested at the ISP workplace provided by Slovak Post. This is precisely because Slovak Post has assisted staff who are qualified and could provide this service quickly and professionally after detailed training. Another advantage that Slovak Post has is that this national postal operator has many years of experience in providing this type of service. After the successful implementation of the new approach, this service could also be provided at the ISP workplace provided by individual public authorities. This pilot project could be implemented primarily in the Žilina Region, and subsequently, after successful implementation, this service could be provided within the entire postal network of the ISP workplace in the Slovak Republic.

\section{Discussion}

Globalization brings development in the social, ecological, cultural, technological and economic spheres. A new trend in the global economy is the development of the digital economy. Within the framework of global development, it is necessary to the area of eGovernment of Slovakia. For this reason, it was necessary to focus on an area that is underdeveloped in the context of the ongoing global trend in the development of digititalisation. That is why we focused on the postal sector, specifically on the ISP workplace, which lags behind other countries in the provision of electronic services. In the development of the workplace, we used strategic management through which we selected new approaches that could be used in the workplace. Subsequently, through primary research, we found out that citizens of Žilina region would accept the conversion from the electronic mailbox for the new service of the ISP workplace. Furthermore, it would be necessary to determine the exact technological procedure on the basis of which the service would be provided by assisted personnel. Within strategic management, the service could bring a competitive advantage, increase profits as well as attract new potential customers. From the point of view of the global economy, this service could be an example for other countries that are implementing the development of digitization within the postal sector. 


\section{References}

1. James, P., Steger, M. B. (2014). A Geneology of 'Globalization': The Career of a Concept. Globalizations, 11(4), 417-434.

2. McCann, P., Acs, Z. J. (2009). Globalization: Countries, Cities and Multinationals. Regional Studies, 45(1),17-32.

3. Rahman, M. M. (2020). Environmental degradation: The role of electricity consumption, economic growth and globalisation. Journal of Environmental Management, 253, 109742.

4. Soltes, V., Stofkova, Z. (2016). Selected aspects of financing regional development in terms of self-government. In: Petranova, D., Rybansky, R., Mendelova, D. (Eds.), Marketing Identity 2016 (pp. 454-461). Trnava: Univ Ss Cyril \& Methodius Trnava.

5. QI, H., Smith, K.A., Yeoman, I. (2018). Cross-cultural event volunteering: Challenge and intelligence. Tourism Management, 69, 1-9.

6. Stofkova, Z., Hraskova, D. (2017). Digital skills in period of digital economy. In: Petranova, D., Rybansky, R., Mendelova, D. (Eds.), Marketing Identity, 2017 (pp. 417425). Trnava: Univ Ss Cyril \& Methodius Trnava.

7. Yera, A., Arbelaitz, O., Jauregui, O., Mugureza, J. (2020). Characterization of eGovernment adoption in Europe. PloS ONE, 15(4), e0231585.

8. Osman, I. A. (2020). Examining E-Government development effects on corruption in Africa: The mediating effects of ICT development and institutional quality. Technology in Society, 61, 101245.

9. Pérez-Morate, R., Pontones-Rosa, C., Núñez-C. N. (2020). The effects of e-government evaluation, trust and the digital divide in the levels of e-government use in European countries. Technological Forecasting and Social Change, 154, 119973.

10. Carter, L., Bélanger, F. (2005). The utilization of e- government services: citizen trust, innovation and acceptance factors. Information Systems Journal, 15(1), 5-25.

11. Liu, L., Li, W., Aljohani, N. R., Lytras, M. D., Hassan, S. U., Nawaz, R. (2020). A framework to evaluate the interoperability of information systems. International Journal of Information Management, 54, 102153.

12. Gasova, K., Stofkova, K. (2017). E-Government as a quality improvement tool for citizens' services. In: Procedia Engineering, Vol. 192, pp. 225-230.

13. Gylptis, L., Christori, M., Vrontis, D., Del Giudice, M., Dimitriou, S., Michael. P. (2020). E-Government implementation challenges in small countries. Technological Forecasting and Social Change, 152, UNSP 119880.

14. Stofkova, Z., Hraskova, D. (2020). Company personnel policy as part of new management approaches in globalization. In: Kliestik, T. (Ed.). Globalization and Its Socio- Economic Consequences, SHS Web of Conferences, Vol. 74, Nr. 04028.

15. Study material. (2013). Strategic management. Retrieved from: https://gtk.unimiskolc.hu/files/5043/STRATEGICKÝ\%20MANAŽMENT.pdf

16. Slovak Post (2020). Business conditions, Provision of integrated services.

17. Slovak Post. (2020). State services at the post office ISP. Retrieved from: https://www.posta.sk/sluzby/sluzby-statu-na-poste

18. Czech Post. (2020). Czech Point. Retrieved from: https://www.ceskaposta.cz/sluzby/egovernment/czechpoint

19. Ministry of the Interior of the Czech Republic. (2020). Czech Point. Retrived from : https://www.mvcr.cz/clanek/czech-point-czech-point.aspx 